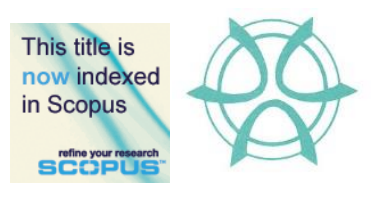

PLANNING MALAYSIA:

Journal of the Malaysian Institute of Planners

VOLUME 16 ISSUE 3 (2018) Page 36 - 45

\title{
RURAL DEVELOPMENT AND THE LEVEL OF PUBLIC FACILITIES PROVISION FOR YOUTH IN MALAYSIA
}

\author{
Dasimah Omar', Kamarul Ariff Omar $^{2}$, Zuriyati Kamaludin ${ }^{3}$, Saberi Othman ${ }^{4}, \&$ \\ Zaharah Mohd Yusoff ${ }^{5}$ \\ ${ }^{1,2,3,5}$ Faculty of Architecture, Planning and Surveying \\ UNIVERSITI TEKNOLOGI MARA, MALAYSIA
}

${ }^{4}$ UNIVERSITI PENDIDIKAN SULTAN IDRIS

\begin{abstract}
The national agenda consistently prioritised the rural development and poverty eradications in Malaysia. The Rural Transformation Programme from 2016 till 2020 outlines six focus areas namely, Rural Infrastructure, Youth Development, Economy, Entrepreneurship, Human Capital and Delivery System. Guided by these principles, the strategies and programmes for rural development and poverty eradication have focused on increasing the productivity as well as improving the quality of life. The objective of this research is to evaluate the level of usage and satisfaction towards facilities provided for youth living in the rural areas. The study areas selected are Jengka, Pahang and Kota Samarahan, Sarawak. The variables for the assessment include adequacy ratio, usage satisfaction, accessibility and maintenance of existing public facilities. The results were analysed to measure the level of provision of public facilities provided for the youth who are living in rural areas. It was found that public facilities including multipurpose hall, public library, mosque, temple and church are provided in both study areas. However, their usage among the youth was rather discouraging, except for mosque, musolla and church.
\end{abstract}

Keywords: youth, rural development, public facilities, utilisation, satisfaction 
PLANNING MALAYSIA

Journal of the Malaysia Institute of Planners (2018)

\section{INTRODUCTION}

Malaysia has had a long and far reaching experience in developing its rural sector and bringing down the incidence of poverty from $58.7 \%$ in 1970 to $1.6 \%$ in 2014 (Ministry of Rural Development, n.d.). The rural programmes are considered as efficient, agile and effective. These efforts, together with the continuous growth of the Malaysian economy have succeeded in creating job opportunities that leads to higher income in rural areas. The Rural Transformation Programme with the theme of Rural Modernisation was launched in 2015. The objective was to ensure the rural areas are provided with public facilities and accessibility akin to urban standard. Every village in Malaysia will be connected via roads, 24 hours electricity and treated water by 2020 .

Youth is indicated as a person between the age where he/she may leave compulsory education, and the age at which he/she finds his/her first employment (Omar, Omar, Othman, \& Mohd Yusoff, 2016). In Malaysian context, there were 13.3 million youth population age between $15-40$, representing $46 \%$ of the total Malaysian population (Raja Kasim, Zulkharnain, Hashim, Wan Ibrahim, \& Yusof, 2014). However, the total number of youth involvement in youth societies or organisation in Malaysia is only $23 \%$ or 3,157,900 million (Yeon et al., 2016). Youth should dynamically take part in community programmes in making the society more liveable and efficient to all age group inside the community social hierarchy. The Malaysian Youth Policy (MYP) had replaced the National Youth Development Policy (NYDP) 1997. Gradually, the age limit is now changing from 15 to 30. The Secretary-General of the United Nations Population Fund said, 'The world has the largest younger generation in history. I place great hope in their power to shape our future' (UNFPA, 2015). He mentioned the youth as the hope of future since they see the world with fresh eyes and represent a staggering amount of human potential. Yet too many of them are trapped in poverty, with few opportunities to learn or to earn a decent living.

\section{LITERATURE REVIEW}

The public facilities provided for youth in rural areas must be in accordance with the needs of the youth. This will encourage them to visit and utilise public facilities provided near their settlement. Indirectly, this will increase the social interaction among youth in rural areas.

Youth in rural communities also have another set of education-related issues that compound economic factors (Smith, 2014). Because of distance and inadequate transportation, rural youth have fewer opportunities for important unstructured social interaction, creating insufficient social support for healthy behaviours and reliance on accessible, structured public programmes (Edwards, Miler, \& Blackburn, 2011). Therefore, rural development is to urbanise the rural area into a conducive area with excellent access to modern infrastructure, entrepreneurship, high income, preservation of environment and cultures 
Dasimah Omar, Kamarul Ariff Omar, Zuriyati Kamaludin, Saberi Othman, \& Zaharah Mohd Yusoff Rural Development and the Level of Public Facilities Provision for Youth in Malaysia

(Sajilan, 2016). In this respect, the location of public facilities in rural areas should be within distance easily accessible by youth. A convenient distance between residential units and public facilities will increase youth satisfaction level towards the facilities provided. Perry (1988) emphasised that a successful planning development is a district with relevant commuting distance connecting residential areas and public facilities. Precisely, it is the main factor contributing to the minimal visit from the rural youth. Most of them have no transportation; a walking distance to public facilities will escalate the number of visitors. Other suggestion is to provide shuttle bus services to connect the rural youth to the public facilities.

According to CSIR (2000), a country should invest in the empowerment, education and employment of their youth. Hence, public facilities provision is generally seen as government responsibility. Public facilities are defined as those basic services, which cannot be supplied directly to the individual dwelling unit and as a result are utilised away from the individual residential dwelling unit within the public environment. Public facilities satisfy specific individual or community needs - including safety and security, communication, recreation, sport, education, health, public administration, religious, cultural and social.

\section{RESEARCH METHODOLOGY}

The scope of this study is the evaluation of rural public facilities provision in relation to utilisation and satisfaction by the youth. Data was obtained through questionnaire survey involving 260 randomly selected respondents whose age are between 15-25 years old. The number of respondents were equally divided between the two study areas; which are Jengka Pahang and Kota Samaahan, Sarawak. Jengka, Pahang is located 55 kilometers from Maran District and 127 kilometers from the state capital Kuantan. It was one of the rural development schemes under the Lembaga Kemajuan Tanah Persekutuan (Federal Land Development Authority, FELDA). Under the scheme, settlers were awarded with land for cultivation of oil palm or rubber. FELDA Jengka is the largest FELDA scheme in Malaysia and also one of the succesfull government's agricultural projects to eradicate rural poverty. It contains 37 clusters with a total population of 15,000 (FELDA, 2018). Figure 1 shows the location of FELDA Jengka, Pahang.

Kota Samarahan, Sarawak is located in the sub-urban of Kuching. It is the main administrative centre in Samarahan district and has an area of 508.1 square kilometres. The total population was 157,792 in year 2014. The main economic activity in Kota Samarahan is agricultural. Majority of the people work in the coconut, oil palm and pineapple plantations. 
PLANNING MALAYSIA

Journal of the Malaysia Institute of Planners (2018)

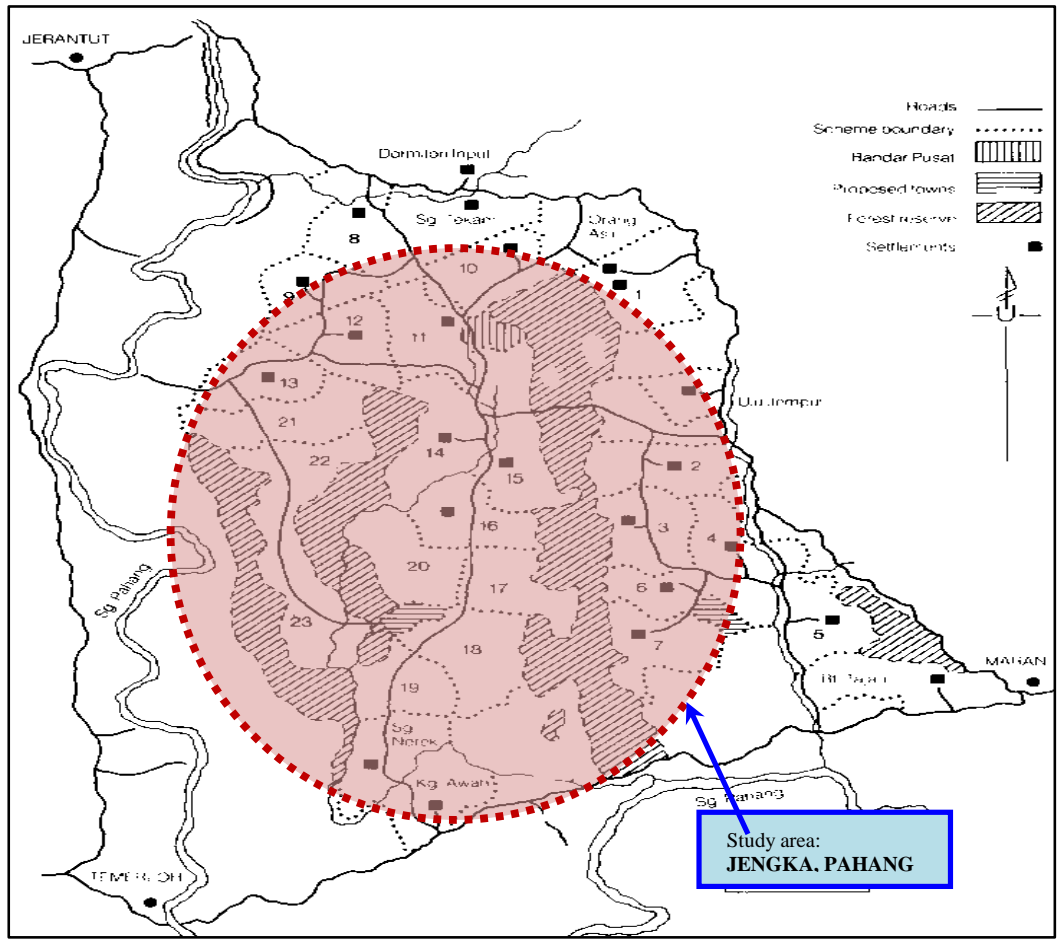

Figure 1: Study area FELDA Jengka, Pahang Source: FELDA (2018)

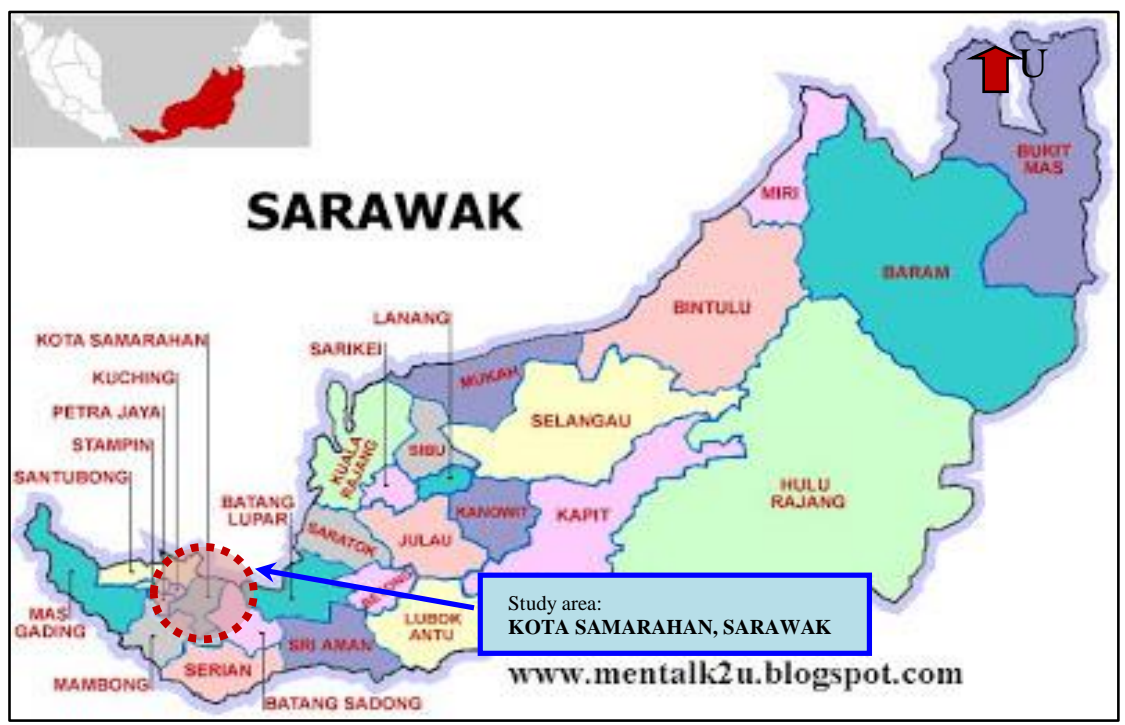

Figure 2: Study area: Kota Samarahan, Sarawak Source: Viamichelin.com (n.d.) 
Dasimah Omar, Kamarul Ariff Omar, Zuriyati Kamaludin, Saberi Othman, \& Zaharah Mohd Yusoff Rural Development and the Level of Public Facilities Provision for Youth in Malaysia

Respondents from the two study areas were given a questionnaire consisting of two (2) sections. Section A deals with respondents demographic background, and Section B on respondents' utilisation and satisfaction level of existing public facilities in their residential areas. Responses for Section B were recorded based on 5-point Likert scale, with ' 1 ' being less satisfied and ' 5 ' being most satisfied. Data from the survey were analysed using descriptive statistical tools available in SPSS software to derive frequencies, means and standard deviations.

\section{RESULTS AND FINDINGS}

\section{Respondents' Background}

In terms of religion, the overall majority of respondents were Muslims (68.1\%), followed by Christian (20.4\%), Buddhist (6.5\%) and Hindu (5.0\%). Respondents from Jengka, Pahang were predominantly Muslims (76.9\%), while in Kota Samarahan main religions of respondents were Islam (59.2\%) and Christianity $(40.8 \%)$.

$148(56.9 \%)$ of respondents were male, and $112(43.1 \%)$ were female. $44.2 \%$ of the respondents were students, $37.7 \%$ were employed and the remaining $18.1 \%$ were unemployed. $3.8 \%$ of respondents have household income within the range of RM2,501 to RM3,000 per month, but also $15.8 \%$ respondents with monthly household income less than RM500. Youths who work after school were paid lower salary and being employed as labourers, sales person, storekeepers and café servers. However, there were youths who have regular jobs such as teachers, quantity surveyors, accountants, civil servants and police, and commanded better pay. However, the percentage was among the lowest.

\section{Distribution of Respondents based on Residential Areas}

Table 1 shows that, in Jengka, Pahang, majority of the respondents were residing FELDA settlement (82). The rest were from the traditional villages (19) and Kampung Baru Cina (Chinese new villages) (18). For Kota Samarahan, most of respondents were from traditional villages (45), longhouses (29) and flats (37).

Table 1: Distribution of respondents based on residential area

\begin{tabular}{lcccccccc}
\hline Location & $\begin{array}{c}\text { FELDA } \\
\text { settlement }\end{array}$ & Estate & $\begin{array}{c}\text { Traditional } \\
\text { village }\end{array}$ & $\begin{array}{c}\text { Kg. Baru } \\
\text { Cina }\end{array}$ & $\begin{array}{c}\text { Long } \\
\text { house }\end{array}$ & $\begin{array}{c}\text { Squatter } \\
\text { house }\end{array}$ & Flat & Total \\
\hline Jengka & 82 & 2 & 19 & 18 & 0 & 0 & 9 & 130 \\
Kota Samarahan & 0 & 6 & 45 & 0 & 29 & 13 & 37 & 130 \\
\hline Total & & & & & & & & 260 \\
\hline
\end{tabular}




\section{Vehicle Ownership}

Table 2 shows that majority of the respondents $(42.3 \%)$ did not own any vehicle. However, $33.1 \%$ owned a motorcycle, $18.1 \%$ owned a car/van, and $6.5 \%$ owned a bicycle. With majority of youth do not own a vehicle, it is therefore important that public facilities should be located at strategic places to increase youth's accessibility to the facilities.

Table 2: Type of vehicles owned by youth

\begin{tabular}{lcc}
\hline Types & No. of Respondents & Percentage \\
\hline No vehicle & 110 & 42.3 \\
Bicycle & 17 & 6.5 \\
Motorcycle & 86 & 33.1 \\
Car / van & 47 & 18.1 \\
\hline Total & 260 & 100.00 \\
\hline
\end{tabular}

\section{Availability and Use of Public Facilities}

Table 3 shows the responses from respondents regarding the availability of public facilities in their residential areas and their utilisation of the facilities. For Jengka, the highest score in terms of availability were multi-purpose hall $(97.7 \%)$ and mosque (97.2\%). Mosque also received highest utilisation score in Jengka (85.5\%). Despite its high score for availability, only $50.8 \%$ of the respondents said that they have used the multi-purpose hall. There are 5 mosques in Jengka including Masjid Jamek FELDA Jengka 16, Masjid FELDA Semarak Jengka 15, and Masjid Huda FELDA Lepar Utara 1, 2 and 4 (JAKIM, 2014).

Table 3: Public facilities availability and utilisation

\begin{tabular}{|c|c|c|c|c|c|c|c|c|}
\hline \multirow{3}{*}{$\begin{array}{l}\text { Types of public } \\
\text { facilities }\end{array}$} & \multicolumn{4}{|c|}{ Availability of public facilities (\%) } & \multicolumn{4}{|c|}{$\begin{array}{l}\text { The use of public facilities by } \\
\text { respondents }(\%)\end{array}$} \\
\hline & \multicolumn{2}{|c|}{ Jengka } & \multicolumn{2}{|c|}{ Kota Samarahan } & \multicolumn{2}{|c|}{ Jengka } & \multicolumn{2}{|c|}{ Kota Samarahan } \\
\hline & Yes & No & Yes & No & Yes & No & Yes & No \\
\hline Public library & 35.4 & 64.6 & 37.7 & 62.3 & 20.8 & 79.2 & 30.2 & 69.8 \\
\hline Multipurpose hall & 97.7 & 2.3 & 46.9 & 53.1 & 50.8 & 49.2 & 35.4 & 64.6 \\
\hline Mosque & 97.2 & 2.8 & 83.3 & 16.7 & 85.5 & 14.5 & 54.6 & 45.4 \\
\hline Musolla & 94.2 & 4.8 & 65.9 & 49.1 & 77.8 & 22.2 & 54.6 & 45.4 \\
\hline Buddhist Temple & 40.5 & 49.5 & 18.5 & 81.5 & 10.9 & 89.2 & - & 100 \\
\hline Hindu Temple & 10.8 & 89.2 & 9.2 & 90.8 & 10.8 & 89.2 & - & 100 \\
\hline Church & 0 & 0 & 64.6 & 35.4 & 0 & 100 & 45.4 & 54.6 \\
\hline
\end{tabular}

For Kota Samarahan, mosque also received highest score in terms of availability $(83.3 \%)$, followed by musolla (65.9\%) and church (64.6\%). In terms of utilisation, $54.6 \%$ of the respondents responded that they have used mosque and musolla and $45.4 \%$ have used the church. There are four mosques provided in Kota Samarahan such as Masjid Darul Taqwa, Masjid Ali Fatimah, Masjid Darul Islam Wal Muslimin, and Masjid Darul Naim (JAKIM, 2014). 
Dasimah Omar, Kamarul Ariff Omar, Zuriyati Kamaludin, Saberi Othman, \& Zaharah Mohd Yusoff Rural Development and the Level of Public Facilities Provision for Youth in Malaysia

The high utilisation score for mosque is in line with earlier finding that shows majority of the respondents were Muslims, followed by Christians. In addition, apart from praying, mosques are also used as venues for religious talk (ceramah) and community programmes such as gotong royong, hence increasing their use among the respondents.

Public library use among the respondents were low in both Jengka (20.8\%) and Kota Samarahan (30.2\%). This may be related to the generally lower education attainment by the respondents (Table 4). At the same time, library also received low score in terms of availability (Table 3), indicating that many of the respondents were not aware of library being provided, hence, did not use it. Additionally, current Internet lifestyle may also affect the level of library use since references can be easily accessed on the Internet without having to visit the library.

Public library serves as a place for educational purposes and cultural enrichment. A big challenge inn increasing the use of public library in rural areas is the educational background of the rural youth.

Table 4: Cross-tabulation of respondents' education level and employment status

\begin{tabular}{lccccc}
\hline \multirow{2}{*}{$\begin{array}{c}\text { Education } \\
\text { level }\end{array}$} & Students & Employed & $\begin{array}{c}\text { Unemployed (Not } \\
\text { active looking for job) }\end{array}$ & $\begin{array}{c}\text { Unemployed } \\
\text { (Active looking for } \\
\text { job) }\end{array}$ & Total \\
\hline UPSR & 15 & 2 & 0 & 0 & 17 \\
PMR & 35 & 3 & 0 & 1 & 39 \\
SPM & 49 & 68 & 29 & 10 & 156 \\
STPM & 9 & 4 & 0 & 1 & 14 \\
Certificate & 1 & 4 & 0 & 2 & 7 \\
Diploma & 3 & 13 & 0 & 4 & 20 \\
Degree & 3 & 4 & 0 & 0 & 7 \\
\hline Total & 115 & 98 & 29 & 18 & 260 \\
\hline
\end{tabular}

\section{Level of Satisfaction on the Physical Aspects of Public Facilities}

Table 5 shows respondents' level of satisfaction towards public facilities provided in their areas in terms of adequacy, usage, distance, accessibility and maintenance. In terms of overall satisfaction, respondents in all aspects measured ranked mosque highest. Musolla also scored well, having been ranked 2 in three out of the five aspects measured. Musolla was ranked 3 in terms of usage and distance. Church came third, having been ranked 2 in terms of usage and distance, and ranked 3 in the other aspects measured. 
Mosques in Malaysia nowadays are no longer confined as places for performing prayers, but also as venues for a host of other religious and social activities. Mosques are being used as venues for religious talk, wedding reception, studying circle, to name a few. Increased diversity in the activities being held at mosques helps increased their usage satisfaction among youth.

The number of mosque provided in an area ensures its satisfaction level in terms of adequacy, distance and accessibility. As mentioned earlier, there are 5 mosques are provided in Jengka and 4 in Kota Samarahan. This enables mosque locations can be spread out in the areas, resulting in shorter distance between mosque and residential areas, thus increasing its accessibility to the residents.

Table 5: Level of satisfaction on the physical aspects of public facilities

\begin{tabular}{|c|c|c|c|c|c|c|c|c|c|c|}
\hline \multirow{2}{*}{$\begin{array}{c}\text { Public Facilities } \\
\text { Provided in Both } \\
\text { Rural Areas }\end{array}$} & \multicolumn{2}{|c|}{ Adequacy } & \multicolumn{2}{|c|}{ Usage } & \multicolumn{2}{|c|}{ Distance } & \multicolumn{2}{|c|}{ Accessibility } & \multicolumn{2}{|c|}{ Maintenance } \\
\hline & 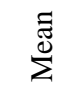 & 䒕 & 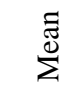 & 崩 & $\sum_{\Sigma}^{\Xi}$ & 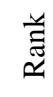 & $\sum_{\Sigma}^{\Xi}$ & 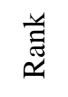 & $\sum_{\Sigma}^{\Xi}$ & 芴 \\
\hline Library & 3.36 & 5 & 3.46 & 6 & 3.31 & 6 & 3.28 & 7 & 3.41 & 6 \\
\hline Multipurpose Hall & 3.57 & 4 & 3.59 & 5 & 3.61 & 5 & 3.70 & 5 & 3.38 & 7 \\
\hline Mosque & 4.33 & 1 & 4.39 & 1 & 4.29 & 1 & 4.38 & 1 & 4.28 & 1 \\
\hline Musolla & 4.23 & 2 & 4.22 & 3 & 4.16 & 3 & 4.22 & 2 & 4.16 & 2 \\
\hline Buddhist Temple & 3.19 & 6 & 3.69 & 4 & 3.69 & 4 & 3.81 & 4 & 4.06 & 4 \\
\hline Hindu Temple & 3.07 & 7 & 3.36 & 7 & 3.07 & 7 & 3.57 & 6 & 3.50 & 5 \\
\hline Church & 4.19 & 3 & 4.26 & 2 & 4.24 & 2 & 4.09 & 3 & 4.07 & 3 \\
\hline
\end{tabular}

\section{CONCLUSION}

Public facilities including multipurpose hall, public library, mosque, temple and church are provided in Jengka, Pahang and Kota Samarahan, Sarawak. Based on the data collected from the youth population living in these areas, majority of them are aware of the existing public facilities. Nevertheless, only few from this targeted group are interested to participate in using the public facilities. Further studies are required to determine the factors that caused this situation.

Public facilities are related to basic needs. Government and nongovernmental organisations are responsible for providing public facilities and make them available for the rural youth. A routine monitoring and maintenance activities are necessary to ensure the public facilities are operating at their full capacities. A multipurpose facility clusters would improve the public facility planning in rural area by located together several public facilities. The number and proportion area of public facilities depend on the demand of the locals. This would allow for easy access and enable them to accomplish various tasks on a single journey.

The local planning authorities and other relevant parties should ensure that public facilities provided in rural areas are in accordance with published planning standards and in accordance with current requirements. To encourage 
Dasimah Omar, Kamarul Ariff Omar, Zuriyati Kamaludin, Saberi Othman, \& Zaharah Mohd Yusoff Rural Development and the Level of Public Facilities Provision for Youth in Malaysia

usage, public facilities must be located at strategic locations, close to residential areas and easily accessible by the public. Stakeholders such as rural youth should be engaged to hear their views to ensure that public facilities provided meet their needs and requirements as well.

\section{ACKNOWLEDGEMENT}

This research was made possible through the Long-term Research Grant Scheme (LRGS 2014-0006-106-42) involving a collaboration between Universiti Pendidikan Sultan Idris Perak, Universiti Teknologi MARA Shah Alam, Universiti Putra Malaysia and Universiti Malaysia Kelantan. Special thanks to the supportive respondents and friends in ensuring the success of this research.

\section{REFERENCES}

Council for Scientific and Industrial Research [CSIR] (2000). Guidelines for human settlement planning and design. Pretoria: CSIR Building and Construction Technology.

Edwards, M. B., Miller, J. L., \& Blackburn, L. (2011). After-school programs for health promotion in rural communities: Ashe County Middle School 4-H After-School Program. Journal of Public Health Management and Practice, 17(3), 283-287.

FELDA (2018). Lembaga Kemajuan Tanah Persekutuan (FELDA) - Jengka. Retrieved December 23, 2017 from http://www.felda.net.my/index.php/program-qurbanperdana-felda/24-korporat/113-jengka

Jabatan Kemajuan Islam Malaysia [JAKIM] (2014). Portal rasmi masjid Malaysia. Retrieved from http://masjid.islam.gov.my/

Ministry of Rural Development (n.d.). Data asas Malaysia 2014. Retrieved from http://www.rurallink.gov.my/wp-content/uploads/2015/05/1-DATA-ASASMALAYSIA1.pdf

Smith, D. (2014). Collaboration between rural school and public youth services librarian. New Library World, 115(3/4), 160-174.

Omar, D., Omar, K. A., Othman, S., \& Mohd Yusoff, Z. (2016). Walkability design for Urban Public Housing Park. Environment-Behaviour Proceedings Journal, 1(3), 311-317.

Perry, C (1998). The Neighbourhood Unit (Reprint) (pp. 25-44). London: Routledge/Thoemmes.

Raja Kasim, R. S., Zulkharnain, A., Hashim, Z., Wan Ibrahim, W. N., \& Yusof, S. E. (2014). Regenerating youth development through entrepreneurship. Procedia Social and Behavioral Sciences, 129, 322-327.

Sajilan, S. (2016, August). Urbanize the rural: New direction in developing entrepreneurs for sustainable development. RRPG $7^{\text {th }}$ International Conference and Field Study in Malaysia. August 15-17, Skudai, Johor, Malaysia.

United Nations Population Fund [UNFPA] (2015, June 1). Youth empowerment, education, employment key to future development. Retrieved from https://www.unfpa.org/news/youth-empowerment-education-employment-keyfuture-development 
PLANNING MALAYSIA

Journal of the Malaysia Institute of Planners (2018)

Viamichelin.com. (n.d.). Map of Kota Samarahan - Michelin Kota Samarahan map. Available at: https://www.viamichelin.com/web/ [Accessed December 23, 2017]

Yeon, A. L., Abdullah, S. A. J., Arshad, R., Ayub, Z. A., Azhar, A., \& Suhaimi, S. (2016) Youth knowledge on the law of youth development in Malaysia. International Journal of Social Science and Humanity, 6(5), 336-340. 